\title{
Roselle (Hibiscus sabdariffa L.) cultivars calyx produced hydroponically: Physicochemical and nutritional quality
}

\author{
Jeny Hinojosa-Gómez ${ }^{1}$, César San Martin-Hernández ${ }^{1}$, José B. Heredia ${ }^{1}$, Josefina León-Félix¹, \\ Tomás Osuna-Enciso ${ }^{1}$, and Marīa D. Muy-Rangel ${ }^{1 *}$ \\ ${ }^{1}$ Centro de Investigación en Alimentación y Desarrollo, A.C. Coordinación Culiacán, Carretera Eldorado km 5.5, Campo el Diez, \\ 80110 Culiacán Rosales, Sinaloa, México. *Corresponding author (mdmuy@ciad.mx).
}

Received: 23 May 2018; Accepted: 22 August 2018; doi:10.4067/S0718-58392018000400478

\begin{abstract}
The chemical constituents of roselle (Hibiscus sabdariffa L.) vary by environmental stimuli and cultivar. The effect of cultivars produced under hydroponic and greenhouse conditions on the mineral composition, chemical and nutraceutical quality of the calyx was evaluated. An experiment was conducted in greenhouse and hydroponic conditions, in a randomized complete design with three replicates and four plants per experimental unit. Treatments were formed by a six roselle cultivars: Cruza Negra, Criolla Huajicori, UAN25-1, UAN16-2, 4Q4, and UAN6-Puga. Principal component analysis (PCA) showed that 'Cruza Negra' is the best cultivar because it presents the highest values of total and insoluble fiber (395 and $260 \mathrm{~g} \mathrm{~kg}^{-1}$ dry basis [db]), total phenols (29.178 mg kg-1 db), anthocyanins (18.133 mg kg-1 db), 2,2-diphenyl1-picrylhydrazyl (DPPH; $645 \mathrm{mg} \mathrm{kg}^{-1} \mathrm{db}$ ), and the absorption capacity of oxygen radicals (ORAC; $240 \mathrm{mg} \mathrm{kg}^{-1} \mathrm{db}^{\text {) The }}$ highest contribution of minerals was observed in 'Cruza Negra' (K, Na, Zn, and $\mathrm{Cu}$ ) and 'Criolla Huajicori' $(\mathrm{Ca}, \mathrm{Mg}$, $\mathrm{S}$, and $\mathrm{Mn}$ ), contributing significantly to the recommended daily intake (RDI). Variability was evident in all the quality characteristics evaluated in the greenhouse roselle calyx. Ash, total and insoluble fiber, phenols, anthocyanins, DPPH, and ORAC contributed the most to the nutritional and nutraceutical quality of the roselle calyx. These variables were influenced by the cultivar.
\end{abstract}

Key words: Anthocyanins, composition, fiber, Hibiscus sabdariffa, main components, quality.

\section{INTRODUCTION}

Roselle (Hibiscus sabdariffa L.) production is conducted in countries with tropical and subtropical regions. This species is primarily cultivated because of the consumption of its calyx (sepals); they are commercially important in the food industry for the production of juices, jams, salads, pigments, and beverages (Borrás-Linares et al., 2015).

On a dry basis, roselle as a food species contains proteins, fats, carbohydrates, raw fiber, and ashes (Adanlawo y Ajibade, 2006), as well as vitamins, organic acids, and phytosterols (Ismail et al., 2008), which are useful for the health of consumers (Da-Costa-Rocha et al., 2014). Roselle is also an important source of minerals, with $\mathrm{K}, \mathrm{Ca}$, and $\mathrm{Mg}$ as well as trace elements $(\mathrm{Fe}, \mathrm{Mn}, \mathrm{Zn}$, and $\mathrm{Cu})$ that the play role in health by functioning as antioxidants or as components of antioxidant enzymes (Evans and Halliwell, 2001).

In addition to its nutritional value, the roselle calyx contains components that confer pharmacological, nutraceutical, and cosmetological properties. Within this group are the polyphenols including delphinidin and cyanidin (Borrás-Linares et al., 2015; Jabeur et al., 2017), that show antioxidant activity in the human body (Wang et al., 2011). 
Crop management and genetic variation are determining factors of the components of the agricultural products that engender benefits to human health. Changes that have demonstrated the effects of the cultivar in terms of the proximal composition of roselle calyx on the contents of its ash, protein, total carbohydrates, and total soluble and insoluble fiber have been reported (Duarte-Valenzuela et al., 2016). Studies on the production of roselle under greenhouse conditions are scarce and designed to evaluate the effect of $\mathrm{N}$ and pathogens on plant development (Rhoden et al., 1993; Hassan et al., 2014); however, no studies have related this information to the quality of the calyx. However, the behavior of the chemical constituents of the roselle calyx obtained in protected agriculture remains unknown. This research evaluated the effect of the cultivar on the mineral composition, as well as the chemical and nutraceutical quality of the roselle calyx produced under hydroponic and greenhouse conditions.

\section{MATERIALS AND METHODS}

The experiment was conducted from October 2015 to March 2016 by roselle calyx in a greenhouse at Culiacan, Sinaloa, Mexico. Maximum and minimum temperatures and relativity humidity were recorded using a data logger (HOBO H8 Onset, Computer Corporation Data Logger, Massachusetts, USA) throughout the development cycle of the crop inside the greenhouse (Figure 1).

The roselle 'Cruza Negra', 'UAN16-2', 'Criolla Huajicori', 'UAN6Puga', 'UAN25-1', and '4Q4' were provided by the Autonomous University of Nayarit, Mexico. The seedlings were produced in 120-well germination trays with a mixture of peat substrate:perlite $(70: 30 \mathrm{v} / \mathrm{v})$. The transplantation that occurred in the greenhouse was conducted with 17-d-old seedlings. Each seedling was placed in a polyethylene bag with $13 \mathrm{~L}$ substrate (60\% Fluvisol soil and $40 \%$ coconut fiber). The distance between plants was $0.50 \mathrm{~m}$ and $1.0 \mathrm{~m}$ between rows. Through drip irrigation, the Steiner nutrient solution (Steiner, 1961) was supplied at a rate of eight daily 5 min-events, with $4 \mathrm{~L} \mathrm{~h}^{-1}$ drippers.

The fruits were harvested at commercial maturity (capsule opening) 138 to $158 \mathrm{~d}$ after transplantation depending on the cultivar. The calyces were manually separated from the capsule and dehydrated to a constant dry weight in an oven (NAHITA 631, France) at $60^{\circ} \mathrm{C}$ by $36 \mathrm{~h}$. After drying, they were milled in a stainless-steel mill (Mod. 3383-L10; Thomas Scientific, Swedesboro, New Jersey, USA) and screened in an $\mathrm{nr} 40$ mesh for quality determinations.

\section{Proximal and mineral composition}

The humidity, ash, fat, protein $(\mathrm{N} \times 6.25)$, and soluble, insoluble, and total fiber contents were determined using AOAC (1998). Total carbohydrates were obtained via the difference method, where carbohydrates $=100$ - (humidity + protein + fat + total fiber + ash). Total $\mathrm{N}$ was measured via the semi-Kjeldahl method (Bremner, 1996), and P was measured via visible spectrophotometry (Spectrophotometer UV/Vis 6705, Jenway, Stone, UK). Ca, Mg, K, S, Na, Fe, Zn, Mn, and $\mathrm{Cu}$ were quantified via atomic absorption spectrometry (AA FS flame AA 280FS + SIPS 20, Agilent Technologies, Santa Clara, California, USA) according to the AOAC official methods (AOAC, 1998).

Figure 1. Weekly average of relative humidity (RH) and maximum (MAXT) and minimum temperatures (MINT) during the cultivation of roselle.

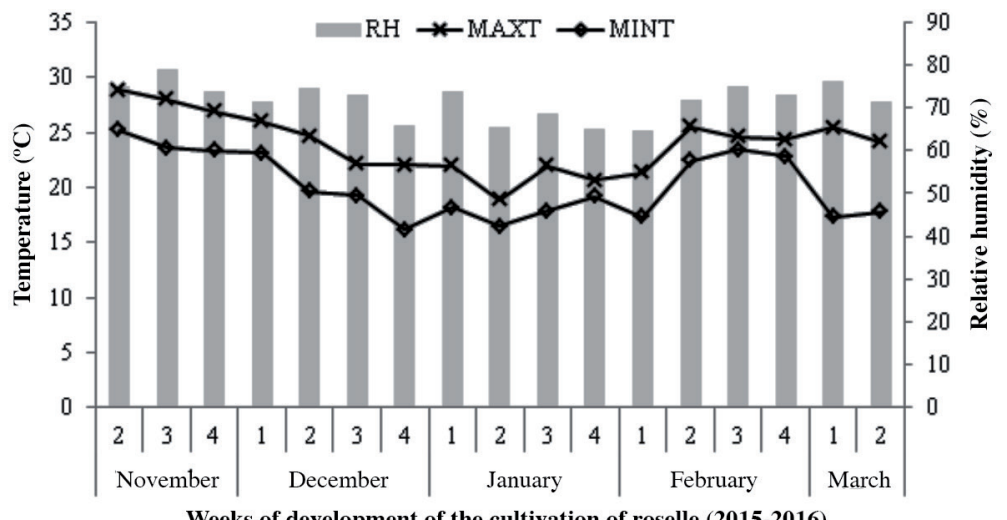

Weeks of development of the cultivation of roselle (2015-2016) 


\section{Nutraceutical attributes}

The anthocyanins were analyzed via absorbance at $520 \mathrm{~nm}$ (Abdel-Aal and Hucl, 1999), using the standard curve of cyanidin-3-glucoside (Sigma-Aldrich, St. Louis, Missouri, USA) and the results were expressed as milligram equivalents of cyanidin-3-glucoside per kilogram dry basis ( $\mathrm{mg} \mathrm{EC} 3 \mathrm{G} \mathrm{kg}^{-1} \mathrm{db}$ ). Total phenols were quantified according to the FolinCiocalteu method (Swain and Hillis, 1959) using the standard curve of gallic acid (Sigma-Aldrich) and the results were expressed as milligram equivalents of gallic acid per kilogram dry basis (mg EAG kg-1 $\mathrm{db}^{2}$. The antioxidant capacity (AC) was determined using two methods: 2,2-diphenyl-1-picrylhydrazyl (DPPH) (Panchawat, 2011) and the absorption capacity of oxygen radicals (ORAC) (Huang et al., 2002). For both methods, the standard curve of Trolox (Sigma-Aldrich). The AC of both methods was converted into equivalent micromoles of Trolox (ET) per gram dry basis ( $\mu$ mol ET g $\left.{ }^{-1} \mathrm{db}\right)$. The three response variables were evaluated using a Sinergy HT Microplate reader (BioTek, Winooski, Vermont, USA).

\section{Color analysis}

Color attributes of roselle calyx were obtained using the CIELCH scale using a spectrophotometer (CM-700d; Konica Minolta, Ramsey, New Jersey, USA). Luminosity (L), hue angle (Hue = arc tan b/a) and chromaticity $\left(\right.$ Chroma $\left.=\sqrt{ }\left[\mathrm{a}^{2}+\mathrm{b}^{2}\right]\right)$ were obtained with OnColor QC version 5 (CyberChrome, Stone Ridge, New York, USA) (Minolta Konica, 2007; Báez-Sañudo et al., 2017).

\section{Statistical analyses}

The results were analyzed using principal component analysis (PCA), ANOVA, and Tukey mean comparisons ( $\mathrm{p} \leq 0.05$ ) by SAS software for Windows, version 9.0 (SAS Institute, Cary, North Carolina, USA). The color was plotted in the CIELCH space with Sigma-Plot, version 11.0 (2008; Systat Software, San José, California, USA). The proximal (nutritional) and nutraceutical attributes of the roselle calyx were analyzed via the Princomp procedure using the correlation matrix, and the components were plotted to visualize the spatial distribution of the cultivars. After PCA, the variables selected for each component, mineral content, and color of the calyx were analyzed using ANOVA (one factor $=$ cultivar), and the means were compared using the Tukey test $(\mathrm{p} \leq 0.05)$.

\section{RESULTS AND DISCUSSION}

\section{Principal component analysis}

In this research, the first two components were chosen, which accounted for 77\% (PC1:50\% PC2:27\%) (Figure 2b) of the total variance according to Kaiser's criterion, that mentions that with the sum of approximately $80 \%$ of the variation is sufficient for the choice of the main components (Braeken and Van Assen, 2017). The coefficients of the first eigenvector (50\%) and correlations showed that the contents of total fiber $(\mathrm{r}=0.78)$, insoluble fiber $(\mathrm{r}=0.92)$, phenols $(\mathrm{r}=0.90)$, anthocyanins $(r=0.85)$, DPPH $(r=0.89)$, and ORAC $(r=0.92)$ were positively associated with component 1 (PC1). Component $2(\mathrm{PC} 2 ; 27 \%)$ was related to humidity $(\mathrm{r}=0.99)$ and inversely related to ash $(\mathrm{r}=-0.99)$ (Figure 2a).

Figure 2. Correlation of nutritional and nutraceutical variables of roselle calyx (a) and a scatterplot of different cultivars (b).
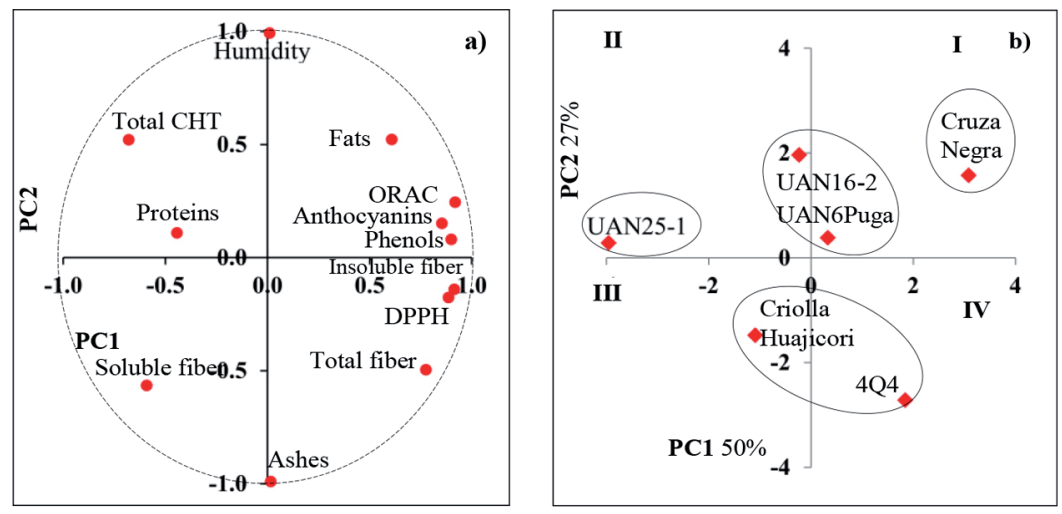
According to PC1 and PC2, the contents of total fiber, insoluble fiber, phenols, anthocyanins, humidity, ash, DPPH, and ORAC presented the highest loads (positive and negative) and were therefore used to define the quality of roselle cultivars. Similar results were reported with regard to calyx obtained in open field cultivation, where total fiber, phenols, and antioxidant activity (ABTS and FRAP) contributed to greater variability and affected the quality of different cultivars (Duarte-Valenzuela et al. 2016).

The dispersion of the cultivars determined by PC1 and PC2 allowed the formation of four clusters (Figure 2b). In quadrant I, the first cluster included 'Cruza Negra', with the best quality in humidity, total fiber, insoluble fiber, total phenols, anthocyanins, DPPH, and ORAC; cluster 2 ('UAN16-2' and 'UAN6Puga') with intermediate values; cluster 3 ('UAN25-1'), showed the lowest contents of quality and cluster four was represented by '4Q4' and 'Criolla Huajicori', showing high values in total fiber and ash.

\section{Proximal variables selected in PC1 and PC2 and mineral composition}

The ANOVA revealed significant differences $(\mathrm{p} \leq 0.05)$ with regard to the cultivar in humidity, ash, total fiber, insoluble fiber, phenols, anthocyanins, DPPH, and ORAC.

In the six cultivars, ash content ranged from $8.6 \%$ to $10.5 \%$ db, with that in ' $4 \mathrm{Q} 4$ ' being higher than those in 'Cruza Negra' and 'UAN16-2' (Figure 3a). These results corroborate the reported values of 9.5\% and $10.6 \% \mathrm{db}$ in open field crops of white and red roselle, respectively, harvested in Sudan (Suliman et al., 2011). '4Q4' and 'UAN6Puga', but not 'UAN25-1', presented the highest total fiber content (Figure 3b), an attribute that can be exploited for industrial use. '4Q4', 'Cruza Negra', and 'UAN6Puga' obtained the highest contents of insoluble fiber. In this research, the total fiber content was slightly lower than the $550 \mathrm{~g} \mathrm{~kg}^{-1} \mathrm{db}$ reported by Sáyago-Ayerdi et al. (2014) for roselle in the open field.

The composition of the minerals of the roselle calyx was affected by the cultivar (Table1), where the highest content was observed for ' UAN25-1'. According to the mineral content and considering a consumption of $25 \mathrm{~g}$ dehydrated roselle, $\mathrm{P}, \mathrm{Ca}, \mathrm{Mn}, \mathrm{Zn}$, and $\mathrm{Cu}$ were the minerals with the highest nutritional intake based on the recommended daily intake (RDI) of each mineral (García-Gabarra, 2006). Of the most important macronutrients, P reached values greater than 30\% RDI for all roselle cultivars, where 'UAN25-1' had the highest content with 45\%. Calcium showed until 39\% of the RDI for all cultivars, with 'Criolla Huajicori' having the highest content and the Mg too. Manganese was the most common micronutrient, surpassing $72 \%$ of its RDI for all cultivars, whereas Zn reached its maximum content in the 'Cruza Negra'. The $\mathrm{Cu}$ content was greater than $18 \%$ of its RDI for the six cultivars, with 'Cruza Negra' having the highest contribution. Comparatively, 'UAN25-1', 'Criolla Huajicori', and 'Cruza Negra' showed the highest ability to absorb and assimilate N in the calyx. The minerals play an important role in the health of consumers.

Figure 3. Contents of humidity, ashes (a), total and insoluble fiber (b) of calyx of different roselle.
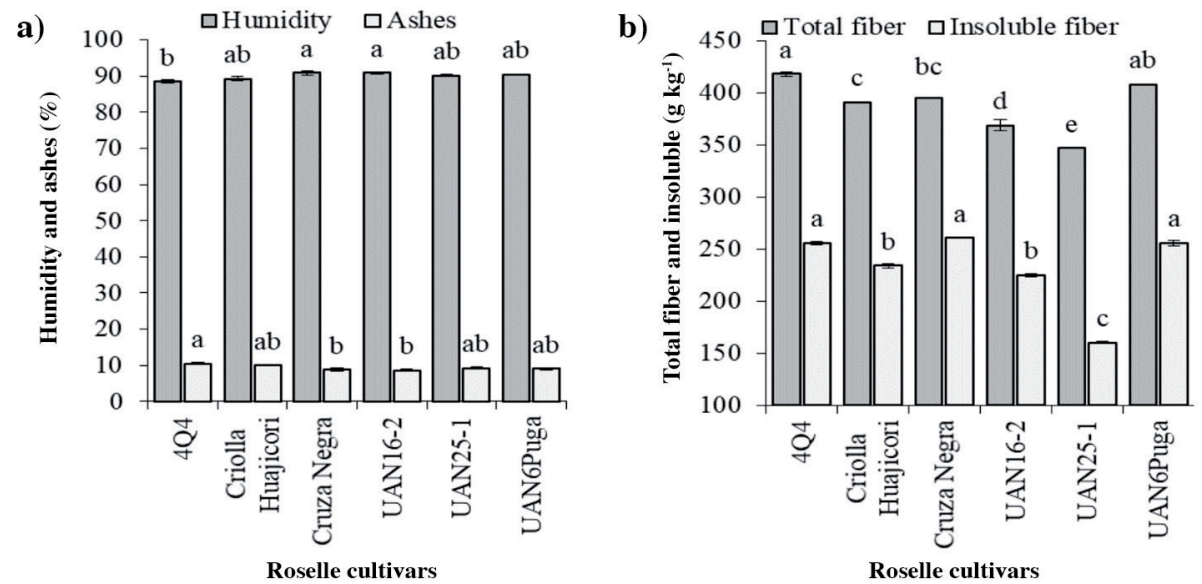

Different letters on bars corresponding to the same response variable indicate significant differences between cultivars according to Tukey test $(\mathrm{P} \leq 0.05)$. Vertical bars correspond to standard deviation. 
Table 1. Mineral content (dry basis) of calyx from different roselle cultivars.

\begin{tabular}{|c|c|c|c|c|c|c|c|c|c|}
\hline & 4Q4 & $\begin{array}{l}\text { Criolla } \\
\text { Huajicori }\end{array}$ & $\begin{array}{l}\text { Cruza } \\
\text { Negra }\end{array}$ & UAN 16-2 & UAN 25-1 & UAN6 Puga & HSD & $\mathrm{CV}$ & RDI \\
\hline & & & & $-\mathrm{mg} \mathrm{kg}^{-1}$ & & & - & $\%$ & $\mathrm{mg} \mathrm{d}^{-1}$ \\
\hline $\mathrm{N}$ & $18251 b$ & $19540 \mathrm{ab}$ & $19042 \mathrm{ab}$ & $18512 b$ & $22007 a$ & $16598 b$ & 2973 & 5.7 & * \\
\hline $\mathrm{P}$ & $8099 \mathrm{c}$ & $10831 b$ & $11115 b$ & $10908 b$ & $11954 a$ & $11040 \mathrm{~b}$ & 443 & 1.5 & 664 \\
\hline $\mathrm{K}$ & $9074 d$ & $14532 \mathrm{c}$ & $19605 a$ & $17088 b$ & $17317 b$ & $15476 \mathrm{c}$ & 1358 & 3.2 & 4700 \\
\hline $\mathrm{Ca}$ & $7264 \mathrm{e}$ & $14061 \mathrm{a}$ & $7914 d$ & $11295 b$ & $10049 \mathrm{c}$ & $6928 \mathrm{e}$ & 417 & 1.6 & 900 \\
\hline $\mathrm{Mg}$ & $2379 d$ & $3259 a$ & $2840 \mathrm{c}$ & $3027 b$ & $2870 \mathrm{bc}$ & $2323 d$ & 173 & 2.3 & 248 \\
\hline $\mathrm{S}$ & $173 b$ & $263 a$ & $92 \mathrm{~cd}$ & $164 b$ & $134 b c$ & $68 d$ & 61 & 14.8 & $*$ \\
\hline $\mathrm{Na}$ & $26 \mathrm{~d}$ & $62 \mathrm{bc}$ & $92 \mathrm{a}$ & $51 \mathrm{c}$ & $80 \mathrm{ab}$ & $59 \mathrm{c}$ & 20 & 11.7 & 1500 \\
\hline $\mathrm{Fe}$ & $28 \mathrm{~d}$ & $59 \mathrm{~d}$ & $187 \mathrm{ab}$ & $212 \mathrm{a}$ & $160 \mathrm{bc}$ & $130 \mathrm{c}$ & 33 & 9.3 & 17 \\
\hline $\mathrm{Mn}$ & $66 c$ & $178 \mathrm{a}$ & $63 c$ & $86 b$ & $58 \mathrm{c}$ & $71 b c$ & 16 & 6.5 & 2 \\
\hline $\mathrm{Zn}$ & $116 \mathrm{~d}$ & $128 d$ & $323 a$ & $83 \mathrm{e}$ & $166 c$ & $180 \mathrm{~b}$ & 13 & 2.9 & 10 \\
\hline $\mathrm{Cu}$ & $7 b$ & $8 \mathrm{~b}$ & $11 \mathrm{a}$ & $9 b$ & $8 \mathrm{~b}$ & $8 \mathrm{~b}$ & 2 & 6.5 & 1 \\
\hline Total & 45483 & 62921 & 61284 & 61435 & 64803 & 52881 & & & \\
\hline
\end{tabular}

Values are mean $\pm \mathrm{SD}(\mathrm{n}=3)$ different letters in the same row indicate significant differences between samples using Tukey test $(\mathrm{P} \leq 0.05)$ HSD: Honest significant difference; CV: coefficient of variation; RDI: recommended daily intake.

*No data available.

The mineral content in the cultivars studied was superior or similar to those in other studies conducted on roselle

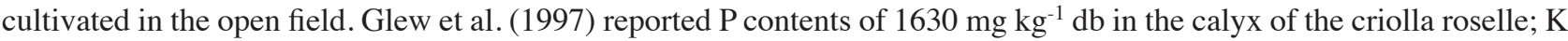
has been quantified as up to $20000 \mathrm{mg} \mathrm{kg}^{-1} \mathrm{db}_{\text {in }}$ the green, red, and dark calyxes of roselle (Babalola et al., 2001). Jung et al. (2013) found Ca contents of $10707 \mathrm{mg} \mathrm{kg}^{-1} \mathrm{db}$ and $\mathrm{Mg}$ contents of $510 \mathrm{mg} \mathrm{kg}^{-1} \mathrm{db}$ in roselle calyx.

The literature is inconsistent concerning the chemical composition of the roselle calyx with regard to $\mathrm{Na}$ (55 to 450

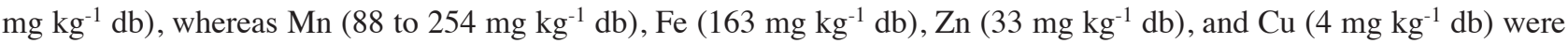
below the content reported in the literature (Babalola et al., 2001; Jung et al., 2013).

\section{Nutraceutical attributes}

The total phenol content in the cultivars varied from 2941 to $29178 \mathrm{mg} \mathrm{EAG} \mathrm{kg}^{-1} \mathrm{db}$; 'Cruza Negra' showed the largest contribution (Figure 4a). In general, these results are low compared with those reported by Borrás-Linares et al. (2015), with 24000 to $100000 \mathrm{mg}^{\mathrm{E} A G ~ \mathrm{~kg}^{-1}} \mathrm{db}_{\text {for }} 25$ Mexican varieties and $38000 \mathrm{mg}^{\mathrm{E}} \mathrm{AG} \mathrm{kg}{ }^{-1} \mathrm{db}_{\text {for }}$ the roselle from Nigeria (Ifie et al., 2018) both of which were cultivated in the open field. In addition, these results are within the average to those reported by Zhang et al. (2018) for 19 mandarin genotypes. The cultivars of this study, 'UAN16-2' and 'UAN25', had phenol contents that were $64 \%$ and $95 \%$ lower than those of the same materials cultivated in the open field reported by Sánchez-Feria et al. (2017); possibly because of UV radiation (Neugart et al., 2012).

The anthocyanin content of the roselle calyx showed similar results to those of the phenols but in a smaller quantity (Figure 4a). In addition, the literature records anthocyanin contents that vary from 9290 to $44080 \mathrm{mg}$ EC3 $\mathrm{G} \mathrm{kg}^{-1} \mathrm{db}_{\text {for }}$ different roselle calyx cultivars under open field crops (Salinas-Moreno et al., 2012; Borrás-Linares et al., 2015). The content of anthocyanins in the calyxes presented here is higher than those reported by Zhang et al. (2016) for three onion

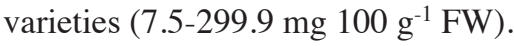

In $\mathrm{AC}$, five materials were significantly equal, with a maximum value at $2140 \mu \mathrm{g} \mathrm{mol}^{-1} \mathrm{ET} \mathrm{db}$ (Figure $4 \mathrm{~b}$ ). DPPH radical was $62 \%$ less than the ORAC, and 'Cruza Negra' and '4Q4' exhibited higher values the others calices and the concentration was similar to Mexican roselle (Borrás-Linares et al., 2015). Regarding ORAC, no studies were found for roselle, however, reports of pigmented materials for amaranth flowers (A. hypochondriacus; $58 \mu \mathrm{mol} \mathrm{ET} \mathrm{g}{ }^{-1} \mathrm{db}$ ) were reviewed, and the results for roselle were lower (Li et al., 2015).

\section{Roselle color}

The cultivar had significant effects $(\mathrm{p} \leq 0.05)$ on the color, $\mathrm{L}$, and ${ }^{\circ} \mathrm{Hue}(\mathrm{H})$ attributes of the roselle calyx. Chroma (C) values were not affected. In the CIELCH color space (Figure 5), the L of the roselle calyx showed values of 29-49 among the cultivars. 'Cruza Negra' and '4Q4' showed the lowest L, which was related to the higher content of pigments (Figure 4a). Studies in Mexican and on imported roselles reported L values between 31 and 79 (Salinas-Moreno et al., 2012; Camelo-Méndez et al., 2016), with a similar variability as shown in this study. 
Figure 4. Contents of phenols and total anthocyanins (a), ORAC and DPPH (b) in the cultivars of roselle.
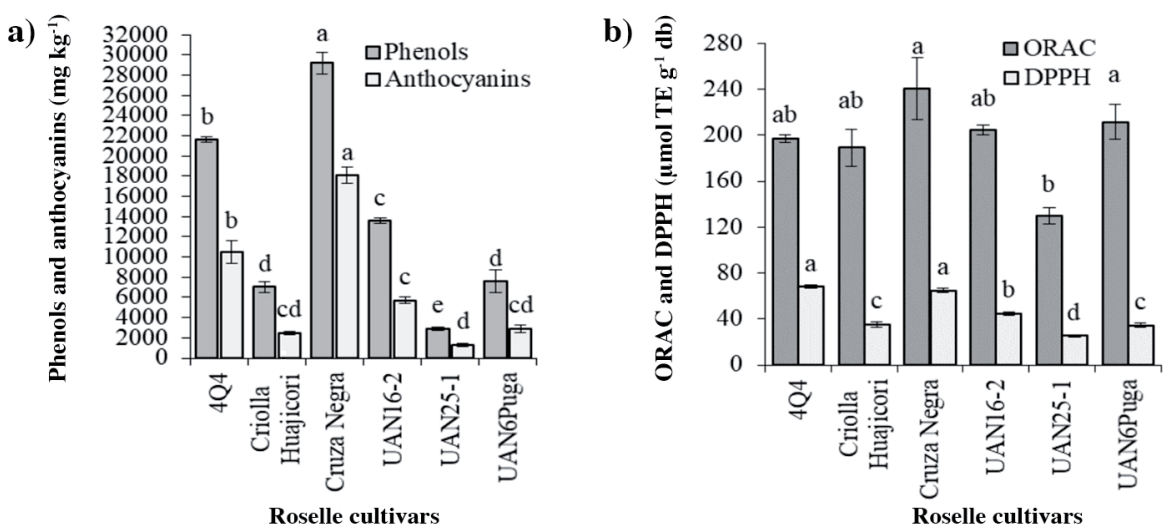

Different letters on bars corresponding to the same response variable indicate significant differences between cultivars according to Tukey test $(\mathrm{P} \leq 0.05)$. Vertical bars correspond to standard deviation.

Figure 5. Color of the six roselle flower cultivars in the CIELCH color space.

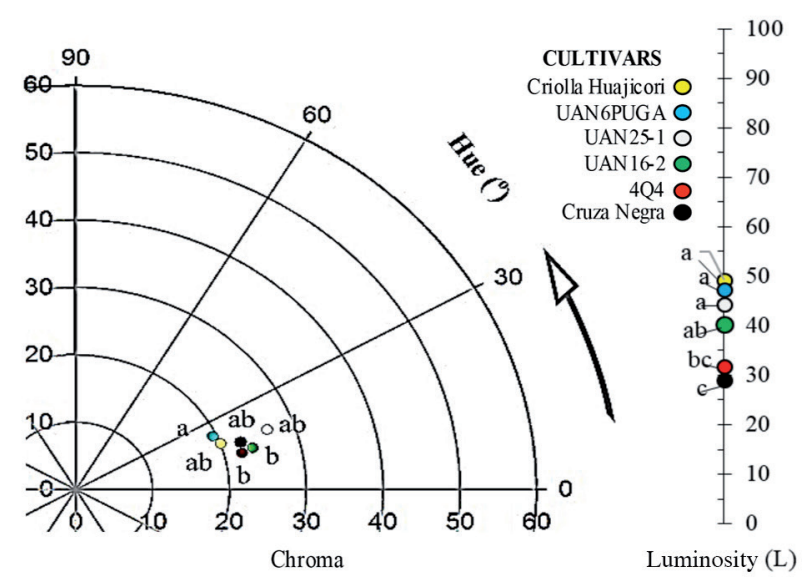

Different letters corresponding to the same response variable indicate significant differences between cultivars according to Tukey test $(\mathrm{P} \leq 0.05)$.

Among the cultivars, the calyx tone angle varied from 14 to $24{ }^{\circ} \mathrm{Hue}$, ' $4 \mathrm{Q} 4$ ' showing the more intense red color $\left({ }^{\circ} \mathrm{Hue}=14\right)$. These results ranged between 12 and $74{ }^{\circ} \mathrm{Hue}$ reported for Mexican roselle (Salinas-Moreno et al., 2012). The Chroma variable enables the differentiation of cultivars.

\section{CONCLUSIONS}

It can be concluded that characteristics evaluated in the roselle calyx are affected by the cultivar. The roselle calyx was corroborated as having antioxidant compounds (e.g., phenols, anthocyanins, and antioxidant activity) in addition to its high content of total and insoluble fiber; however, through the mode of production under hydroponic and greenhouse conditions, this crop showed considerable increases in mineral content. The contents of total fiber, insoluble fiber, phenols, anthocyanins, humidity, ash, DPPH, and ORAC contribute the most to the nutritional and nutraceutical quality of hydroponically produced roselle calyx. The cultivar also influenced these contents. 
Variations in the nutritional and nutraceutical composition of roselle allow the production company to select cultivars according to the production approach, where 'Cruza Negra' can be the cultivar chosen for commercial production given its high contents of phenols, anthocyanins, insoluble fiber and antioxidant capacity, components that are considered as desirable for their benefits to human health.

\section{REFERENCES}

Abdel-Aal, E.S., and Hucl, P. 1999. A rapid method for quantifying total anthocyanins in blue aleurone and purple pericarp wheats. Cereal Chemistry 76:350-354.

Adanlawo, I.G., and Ajibade, V.A. 2006. Nutritive value of the two varieties of roselle (Hibiscus sabdariffa) calyces soaked with wood ash. Pakistan Journal of Nutrition 5:555-557.

AOAC. 1998. Official methods of analysis. $16^{\text {th }}$ ed. Association of Official Analytical Chemists (AOAC), Washington, D.C., USA. Babalola, S.O., Babalola, A.O., and Aworh, O.C. 2001. Compositional attributes of the calyces of roselle (Hibiscus sabdariffa L.) Journal of Food Technology in Africa 6:133-134.

Báez-Sañudo, M.A., Muy-Rangel, M.D., Heredia, J.B., and Adriana, J. 2017. Reducing postharvest softening of papaya (Carica papaya cv. Maradol) by using an aqueous 1-methylcyclopropene application. International Journal of Environmental and Agriculture Research 3:144-151.

Borrás-Linares, I., Fernández-Arroyo, S., Arráez-Roman, D., Palmeros-Suárez, P.A., Del Val-Díaz, R., Andrade-Gonzáles, et al. 2015. Characterization of phenolic compounds, anthocyanidin, antioxidant and antimicrobial activity of 25 varieties of Mexican Roselle (Hibiscus sabdariffa). Industrial Crops and Products 69:385-394.

Braeken, J., and Van Assen, M.A. 2017. An empirical Kaiser criterion. Psychological Methods 22:450.

Bremner, J.M. 1996. Nitrogen-total. In Sparks, D.L. (ed.) Methods of soil analysis. Part 3: Chemical methods. SSSA Book Series 5. p. 1085-1121. Soil Science Society of America (SSSA), Madison, Wisconsin, USA.

Camelo-Méndez, G.A., Jara-Palacios, M.J., Escudero-Gilete, M.L., Gordillo, B., Hernanz, D., Paredes-López, O., et al. 2016. Comparative study of phenolic profile, antioxidant capacity, and color-composition relation of roselle cultivars with contrasting pigmentation. Plant Foods for Human Nutrition 71:109-114.

Da-Costa-Rocha, I., Bonnlaender, B., Sievers, H., Pische, I., and Heinrich, M. 2014. Hibiscus sabdariffa L.-A phytochemical and pharmacological review. Food Chemistry 165:424-443.

Duarte-Valenzuela, Z.N.,Zamora-Gasga, V.M., Montalvo-González, E., y Sáyago-Ayerdi, S.G. 2016. Caracterización nutricional de 20 variedades mejoradas de jamaica (Hibiscus sabdariffa L.) cultivadas en México. Revista Fitotecnia Mexicana 39:199-206.

Evans, P., and Halliwell, B. 2001 . Micronutrients: oxidant/antioxidant status. British Journal of Nutrition 85:S67-S74.

García-Gabarra, A. 2006. Ingesta de nutrientes: Conceptos y recomendaciones internacionales. $2^{\text {a }}$ Parte. Nutritional Hospitalaria 21:437-447.

Glew, R.H., Vander Jagt, D.J., Lockett, C.T., Grivetti, L.E., Smith, G.C., Pastuszyn, A., et al. 1997. Amino acid, fatty acid, and mineral composition of 24 indigenous plants of Burkina Faso. Journal of Food Composition and Analysis 10:205-217.

Hassan, N., Shimizu, M., and Hyakumachi, M. 2014. Occurrence of root rot and vascular wilt diseases in roselle (Hibiscus sabdariffa L.) in Upper Egypt. Microbiology 42:66-72.

Huang, D., Ou, B., Hampsch-Woodill, M., Flanagan, J.A., and Prior, R.L. 2002. High-throughput assay of oxygen radical absorbance capacity (ORAC) using a multichannel liquid handling system coupled with the microplate fluorescence reader in 96-well format. Journal of Agricultural and Food Chemistry 50:4437-4444.

Ifie, I., Ifie, B.E., Ibitoye, D.O., Marshall, L.J., and Williamson, G. 2018. Seasonal variation in Hibiscus sabdariffa (Roselle) calyx phytochemical profile, soluble solids and $\alpha$-glucosidase inhibition. Food Chemistry 261:164-168.

Ismail, A., Ikram, E.H.K., and Nazri, H.S.M. 2008. Roselle (Hibiscus sabdariffa L.) seeds nutritional composition protein quality and health benefits. Food 2:1-16.

Jabeur, I., Pereira, E., Barros, L., Calhelha, R.C., Soković, M., Oliveira, M.B.P., et al. 2017. Hibiscus sabdariffa L. as a source of nutrients, bioactive compounds and colouring agents. Food Research International 100:717-723.

Jung, E., Kim, Y., and Joo, N. 2013. Physicochemical properties and antimicrobial activity of roselle (Hibiscus sabdariffa L.) Journal of the Science of Food and Agriculture 93:3769-3776.

Li, H., Deng, Z., Liu, R., Zhu, H., Draves, J., Marcone, M., et al. 2015. Characterization of phenolics, betacyanins and antioxidant activities of the seed, leaf, sprout, flower and stalk extracts of three Amaranthus species. Journal of Food Composition and Analysis 37:75-81.

Minolta Konica. 2007. Precise color communication: Color control from perception to instrumentation. Konica Minolta Sensing Inc., Osaka, Japan.

Neugart, S., Kläring, H.P., Zietz, M., Schreiner, M., Rohn, S., Kroh, L.W., et al. 2012. The effect of temperature and radiation on flavonol aglycones and flavonol glycosides of kale (Brassica oleracea var. sabellica). Food Chemistry 133:1456-1465.

Panchawat, S. 2011. In vitro free radical scavenging activity of leaves extracts of Withania somnifera. Recent Research in Science and Technology 3:40-43. 
Rhoden, E.G., David, P., and Small, T. 1993. Effect of nitrogen nutrition on Roselle. p. 583-584. In Janick, J., and Simon, J.E. (eds.) New crops. Wiley, New York, USA.

Salinas-Moreno, Y., Zúñiga-Hernández, A.R.E., Jiménez-De la Torre, L.B., Serrano-Altamirano, V., y Sánchez-Feria, C. 2012. Color en cálices de jamaica (Hibiscus sabdariffa L.) y su relación con características fisicoquímicas de sus extractos acuosos. Revista Chapingo Serie Horticultura 18:395-407.

Sánchez-Feria, C., González-Hernández, V.A., Salinas-Moreno, Y., y Cruz-Huerta, N. 2017. Efecto de genotipo y ambiente en la calidad fisicoquímica de variedades mexicanas de Hibiscus sabdariffa L. Agrociencia 51:525-541.

Sáyago-Ayerdi, S.G., Velázquez-López, C., Montalvo-González, E., and Goñi, I. 2014. By-product from decoction process of Hibiscus sabdariffa L. calyces as a source of polyphenols and dietary fiber. Journal of the Science of Food and Agriculture 94(5):898-904.

Steiner, A.A. 1961. A universal method for preparing nutrient solutions of a certain desired composition. Plant and Soil 15:134-154.

Suliman,A.M.,Ali, A.O., Idriss, S.E.A., and Abdualrahman, M.A. 2011.A comparative study on red and white karkade (Hibiscus sabdariffa L.) calyces, extracts and their products. Pakistan Journal of Nutrition 10:680-683.

Swain, T., and Hillis, W.E. 1959. The phenolics constituents of Prunus domestica. I. The quantitative analysis of phenolics constituents. Journal of the Science of Food and Agriculture 10:63-68.

Wang, S.C., Lee, S.F., Wang, C.J., Lee, C.H., Lee, W.C., and Lee, H.J. 2011. Aqueous extract from Hibiscus sabdariffa Linnaeus ameliorate diabetic nephropathy via regulating oxidative status and Akt/Bad/14-3-3 $\gamma$ in an experimental animal model. Evidence-Based Complementary and Alternative Medicine 2011:938126.

Zhang, H., Yang, Y.F., and Zhou, Z.Q. 2018. Phenolic and flavonoid contents of mandarin (Citrus reticulata Blanco) fruit tissues and their antioxidant capacity as evaluated by DPPH and ABTS methods. Journal of Integrative Agriculture 17:256-263.

Zhang, S.L., Peng, D.E.N.G., Xu, Y.C., Lü, S.W., and Wang, J.J. 2016. Quantification and analysis of anthocyanin and flavonoids compositions, and antioxidant activities in onions with three different colors. Journal of Integrative Agriculture 15:2175-2181. 